DR. KATHRYN DAVIDSON (Orcid ID : 0000-0003-3521-3535)

Article type : Special Section Article

\title{
A DECADE OF C40: \\ RESEARCH INSIGHTS AND AGENDAS FOR CITY NETWORKS
}

1. Dr Kathryn Davidson, Faculty of Architecture, Building and Planning, The University of Melbourne, Australia.

2. Professor Brendan Gleeson, Melbourne Sustainable Societies Institute, The University of Melbourne, Australia

3. Professor Lars Coenen, Melbourne Sustainable Societies Institute, The University of Melbourne, Australia

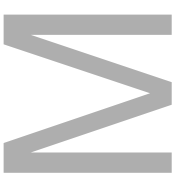

\section{Introduction}

In the last decade there has been a marked growth in formalised city networks. City networks of late have transcended beyond municipal collaborations towards more complex networked governance arrangements (Davidson et al 2019; Davidson \& Gleeson, 2018). Scholars have noted that in the 'networking boom' age, cities can derive clear benefits from engaging in networking activities (Acuto, 2016). As Toly (2008, p. 341) noted, participating in transnational municipal networks provides cities with significant opportunities, amongst others, to enter into 'inter-municipal dialogue[s]' and pool their global influences. City networks are noted also to raise the level of ambition among cities learning from and competing with each other with regard to the deployment of low-carbon innovations and This is the author manuscript accepted for publication and has undergone full peer review but has not been through the copyediting, typesetting, pagination and proofreading process, which may lead to differences between this version and the Version of Record. Please cite this article as doi: $10.1111 / 1758-5899.12740$

This article is protected by copyright. All rights reserved 
policies (Davidson \& Gleeson, 2018; Gordon \& Acuto, 2015; Broto \& Bulkeley, 2013). These new forms of cross national networking are potentially framing and reframing urban governance and strategy, and the way we conceive of cities, and their policies and politics, in an age of planetary urbanisation (Merrifield, 2013; Acuto 2011).

The emergence of networked city climate governance arguably reflects the failure of national and state governments to acknowledge the necessity for a global response to anthropogenic global warming (Sassen, 2014). The evolution of this new field of climate governance has recently been recognized and points to a compelling new 'urban centrality' in global affairs (Bulkeley, Edwards and Fuller, 2014). The concept of 'urban centrality' manifested itself prior to and during the 2015 Paris Conference of Parties (COPs), most notably via the formation of the Compact of Mayors among urban leagues established at the 2014 UNSG Climate Summit. Additional impetus arose from the unifying initiative of all city networks under the leadership of Mike Bloomberg as UN Special Envoy for Cities and Climate Change and the Paris Mayor Anne Hidalgo. The Intergovernmental Panel on Climate Change (IPCC, 2014) now acknowledges that city climate networks are critical in engaging citizens in the development of responses to climate change and also in promoting 'diffusion of climate policies throughout the world' (Falkner, 2016, p. 1112). With the failure of national governments to 'step up' to the challenge of climate change, a compelling space for citybased climate governance and innovative climate action has been created.

Over the last two decades, at least nine urban climate networks have been established around the world. Of these the $\mathrm{C} 40$ network has gained considerable traction by articulating climate change as an urban-driven question and provided city members with certain resources and supports for 'the effective delivery of urban-focused climate initiatives' (Acuto, 2013, p. 840). The $\mathrm{C} 40$ has provided a platform for coordination and knowledge exchange and member cities have delivered over 14,000 city-based climate actions. C40 incorporates some of the most globally influential mayors, self-professed 'global' cities, and is deeply intertwined with major international business and philanthropic actors. Its initial membership of 18 cities at its establishment in 2005 has now increased to 94 affiliated cities in 2019. Ken Livingstone, the former Mayor of London, formed the C40 to address any 'bureaucratic and political obstacles to the effective delivery in urban-focused climate initiatives' (Acuto, 2013, p. 840). First developed by Livingstone to closely follow the Group of Eight (the G8) and Group of 20 (the G20) network model, the network was originally called C20 before being 
later changed to C40 as more member cities joined (Aust, 2015). C40 now includes 94 of the world's largest cities, covering 650 million people and an estimated $25 \%$ of the global GDP.

The aim of this review article is to synthesize insights from the academic literature on C40 and chart a more comprehensive research agenda on city networks within the field of urban climate governance. Whilst our focus is on $\mathrm{C} 40$, we believe that the research insights and questions we draw out are applicable to other urban networks, for example ICLEI, UCLG and Cities Alliance. This article consolidates the academic literature on $\mathrm{C} 40$ within the context of three key themes that are drawn upon from earlier work of Davidson et al., (2019).

1) Political economies of city networks focusing on illuminating the highly sophisticated and complex power dynamics in C40: Who has power and influence to shape the direction and coordinating capacity within city-networks?

2) Knowledge dynamics in city networks: How is knowledge for urban climate action created and distributed in city-networks and how is knowledge translated into action?

3) The transformative influence of city networks for key urban institutions: What are the implications of city networks for traditional institutions that have in the past shaped urban strategy, development and government?

These themes were identified based on a literature review for a critical commentary of urban studies, namely Davidson et al 2019, as priority questions for the field of city networks and urban climate governance. The first theme is important due to the unexamined role of economic power in determining the participation within and priorities of city networks. This question of political economy deserves closer inspection by scholarship. The second theme identified that knowledge dynamics is an under-studied phenomenon in city networks and it is unknown whether the same/or new socio-spatial configurations of knowledge networks are reinforcing/disrupting decision-making processes and outcomes. The last theme points to the understudied implications of city networks for traditional institutions that have in the past shaped urban strategy and development. City networks and their actions potentially challenge the status, methods, and institutional relevance of traditional planning in ways that have not yet been considered in practice and scholarship. We conclude the paper with an emphasis on theme 3 that takes our analysis to a wider plane, outside the C40 frame, considering the implications of networked climate governance for conventional urban institutions, especially 
land use and metropolitan planning. In particular, we point to a new research agenda that considers the effects of city networks for the institutional relevance of traditional planning in ways that have not yet been considered in practice and scholarship. We propose that networked urbanism differs from traditional planning by emphasising relatively fluid fastmoving programs, actions and behavioural changes over the slower conventional means for city shaping, especially land use regulation. We argue a key challenge is to align and potentially synthesise these traditional and new forms of city shaping in an urban age era of rapidly unfolding climate endangerment. We conclude by offering three considerations for critical comment, developing some recent propositions on this theme.

\section{Theme 1: Political economies of city networks}

Who has power and influence to shape the direction and coordinating capacity of citynetworks?

In charting the literature in this theme, we draw upon the broader discussions in urban climate governance and city networks (Smeds \& Acuto, 2018; Gordon \& Johnson, 2017; Davidson \& Gleeson, 2015, 2018), multi-level governance (Dowling et al., 2018; Bulkeley et al., 2014), and international relations (e.g. Betsill and Bulkeley, 2004; Acuto and Rayner, 2016). Questions of power and influence necessarily flow from a political ecology perspective deployed to understand urban climate governance, especially its networked forms, (Davidson \& Gleeson 2014, 2015). This approach reflects that of wider critical urban ecology that interrogates how "the power-laden socioecological relations that shape the formation of urban environments constantly shift between groups of actors and scales" (Swyngedouw \& Heynen, 2003, p.898).

The C40 network has developed a highly sophisticated and well recognised collaborative structure incorporating but not limiting to city governments, major international business and philanthropic actors. From this solid structure, the C40 developed its own profile as a diplomatic actor. City leaders have drawn upon the $\mathrm{C} 40$ to increase coordination, encourage exchanges of knowledge and establish 'network diplomacy' (Acuto, 2013). The development of network diplomacy has resulted with movement beyond traditional international relations to enhance cities' capacity to participate in global governance discourses (Heine, 2008; Acuto 
2013). In this context, Fraundorfer (2017, p. 28) observes that 'the C40 network has also been engaged in boosting its profile as a diplomatic actor'. For example, together with the United Cities and Local Governments Network [UCLG] and ICLEI and other partners, the C40 is a founding partner of Global Covenant of Mayors for climate and energy. This initiative brings together the Covenant of Mayors and the Compact of Mayors, the world's two primary initiatives of cities and local governments to advance their transition to a low emission and climate resilient economy (C40, 2016a). Additionally, the $\mathrm{C} 40$ also works in strong partnership with the Global Commission on the Economy and Climate to develop the Coalition for Urban Transition, which focuses on enhancing the cooperation between cities and national governments to influence national urban policies towards low-carbon urban development (Coalition for Urban Transition [CFUT] 2016).

Furthermore, $\mathrm{C} 40$ cities have actively participated in initiatives that accord with different UN climate frameworks and initiatives such as the Conferences of Parties, and the Rio+20 Summit 2012 (Bouteligier, 2013; Fraundorfer 2017). C40 cities have participated in and lobbied national governments about various climate change policies, such as green urban development (Acuto, 2013). The C40 has also in the past formed partnerships with corporations. For example, the $\mathrm{C} 40$ and Siemens technical partnership, referred to as the GHG Measurement \& Planning Initiative, was designed to help cities measure, plan, and mitigate their greenhouse gas (GHG) emissions (Bouteligier, 2013). Further, Acuto and Rayner (2016) have observed that the network is expanding the nature of their policy agendas to encompass inter-sectoral collaborations, in which the $\mathrm{C} 40$ and WHO Healthy Cities are cooperating. This has developed subnetworks with strong policy focuses on linked health and climate actions. International scholars have suggested that the $\mathrm{C} 40$ has contributed significantly to the development of common planning strategies and shared metropolitan policies and created strong connections between megacities and key international institutions (Acuto, 2013; Davidson and Gleeson 2015; Acuto and Rayner 2016; Pinault and Hansen 2018).

Scholars have noted the C40's capacity to stimulate city engagement towards problemsolving rather than solely for purposes of branding or green-washing (Busch \& Anderberg 2015; Hakelberg 2014). It is unknown though 'how, to what extent, and with what effects city-networks effectively 'govern' their constituent members' (Gordon \& Johnson, 2018, p. 38). As a consequence this raises the capacity of the $\mathrm{C} 40$ to effectively bridge the gap 
between nominal commitments and costly action (Michaelowa \& Michaelowa 2017; Kern \& Bulkeley 2009; Hughes 2016; Bansard, Pattberg \& Widerberg 2017).

Furthermore, the distribution of costs/mitigation burdens among city networks is unresolved. For example, Gordon and Johnson (2018, p. 37) observe that 'sharing the burden of emissions reductions entails a number of challenges that are as yet poorly addressed'. For instance, Deadline 2020 outlines the low-end threshold of \$15,000 per capita, which can potentially exclude a certain number of high-emitting cities such as Mumbai, Dhaka or Kolkata (Gordon and Johnson, 2018). Additionally, this programme also projects the total cost for implementing 14,000 climate actions in C40 cities by 2020 at approximately US $\$ 375$ billion, which critically presents certain issues related to the distribution of social cost. In this context, while $\mathrm{C} 40$ is providing support for their members to secure financial resources (CCFLA, 2015; CDP 2016), it is indisputable that the access to funding for climate actions is still highly contingent upon international donors and national governments (Hickmann, 2016). Consequently, this raises a question for C40 regarding decisions on 'what constitutes a fair and equitable allocation of a global-urban carbon budget' that needs to be addressed in the foreseen future (Gordon and Johnson, 2018, pp. 37-38).

\section{Theme 2: Knowledge dynamics in city networks}

How is knowledge for urban climate action created and distributed in city-networks and how is knowledge translated into action?

The aim of the $\mathrm{C} 40$ network is to deliver a model of evidenced-based, action-oriented, internationally networked urban governance that promotes the exchange of technical knowledge and climate policy insights. Scholars have noted that such knowledge and insights are typically gained from urban experimentation and cross-sector collaboration (Bulkeley \& Broto, 2013; Bulkeley et al. 2016). Even though analytical precision and consensus about what is meant by 'experimentation' and how it differs from related concepts such as 'randomized control trials', 'demonstration projects' and 'innovation' is still lacking, increasingly cities are conceived as 'experimental' (Evans et al., 2016) or seen as designated sites for experiments (Evans, 2011). Situated outside the domain of urban studies yet positioned within political theory, Ansell and Bartenberger (2016) provide a useful typology of experimentation that distinguishes between controlled experimentation, Darwinian experimentation and generative experimentation. Drawing on this typology, we argue that the 
C40 network is in part infusing a logic of Darwinian experimentation on its city members. Based on an evolutionary framework of variation-selection-retention, the $\mathrm{C} 40$ network aims to generate a portfolio of fit-for-purpose 'best practices' through collective, distributed yet parallel experimentation in and by its member cities.

Within the $\mathrm{C} 40$ network, city members have experienced plenty of interactions with others including collaboration, learning and dissemination of innovations to enhance climate policies at city levels (Lee and Van de Meene, 2012; Lee and Jung 2018). In this sense, C40 has served as a forum for its members to communicate and exchange climate initiatives, either directly to other cities at C40 conferences, summits, workshops and events, or indirectly via official publications on C40's website regarding planning guidelines and best practices (Gordon, 2013; Rashidi and Patt 2018). Appendix 1 outlines C40 networks, programs and projects. Within this context, Acuto (2016) noted that in 2015, approximately 75 per cent of the climate actions entered into by $\mathrm{C} 40$ cities were subsequently implemented in other $\mathrm{C} 40$ cities ( 95 per cent of which were then proposed to scale up to greater metropolitan areas). For example, following trials in two C40 cities (New York and Tokyo), Changwon in South Korea subsequently introduced similar 'cool roof' techniques to reflect sunlight and cool buildings. Additionally, C40 (2015) reported that in 2015, around 30 per cent of C40's climate actions were implemented through city-to-city collaboration and 44 per cent of which (13 per cent of total actions) involved cooperation through one of C40's 17 thematic networks. For instance, by participating in the C40 Private Building Efficiency Network, London took advantage of ideas pooled by this network and learnt from Chicago, New York and Houston on how to make its buildings energy-efficient. Notably, the exchange of information and knowledge within this network strongly impacted London's Business Energy Challenge established in 2014, which created a platform for coordination between the Mayor and private sectors to improve the energy efficiency of buildings.

This points to a different experimentation logic for individual city members that is best described as 'generative'. Generative experimentation "can be thought of as a process of generating and iteratively refining a solution concept (an idea, innovation, design, policy, program, etc) based on continuous feedback and with the goal of addressing a particular problem" (Ansell and Bartenberger, 2016, p. 68). This generative logic is more attuned to agency as it emphasizes collective learning, coordination and deliberation in designing a successful solution through accumulated knowledge and experience. For individual city 
members, the $\mathrm{C} 40$ network provides access to significant resources, both tangible and intangible that are not available locally.

To further unpack the C40 network, Pinault and Hansen (2018) have shown that, when partaking in $\mathrm{C} 40$ activities, city mayors obtain great opportunities to engage with other leaders that are considered as peers, in which they can exchange and compare various ideas and solutions to gain useful insights and inspirations. C40 has enabled these city comparisons via different approaches, such as: (1) developing common standards and frameworks for planning, measuring and reporting on city climate actions, from which cities can benchmark and compare their performances against other network's members; or (2) recognising cities' best practices regarding climate actions via C40's annual 'Cities Climate Leadership Awards' and the Cities 100 report (Pinault and Hansen, 2018). It is apparent that C40 has acted as a catalyst to help cities interact with others collectively (e.g., by creating internal communication systems and holding conferences, workshops or summits on C40 best practices and the Climate Change Action Plan) and individually (e.g., by cities working with their network partners to address their specific needs) (Bouteligier, 2013).

To understand coordinated efforts and activities between different actors and cities within the global networked governance of C40, Gordon and Johnson (2017) applied the conceptual lens of orchestration. This is a form of indirect governance characterised by a weakened relationship between governor and governed: the orchestrator works via an intermediary for governing a target audience (Abbott et. al, 2015). For instance, within the Climate Positive Development Program of C40, participating cities (with their associated projects) have come to converge around the common goals of becoming climate positive and delivering lowcarbon developments. Such convergence has been generated in the C40 via the process of political mobilisation amongst different actors - cities such as London, Stockholm, Jaipur; philanthropic organisations including Bloomberg Philanthropies; or non-governmental organisations (NGOs) such as the US Green Building Council and Clinton Foundation. These entities have attempted to orchestrate cities towards specific climate positive actions and joint objectives (Gordon and Johnson 2017; Gordon and Acuto 2015). In this circumstance, it is apparent that the $\mathrm{C} 40$ provides the fundamental institutional context for supporting the delivery of climate positive experiments and projects within its member network. Interestingly, this institutional context is based on a cross-sector collaboration and fluid boundaries between private and public actors. It is therefore important to note that learning 
processes in experimentation are both epistemic and political (Ansell and Bartenberger, 2016, p. 70). "Epistemic learning is learning that expands or refines our scientific knowledge of the world - both of the natural world and or the social world. By contrast, political learning is learning that leads stakeholders to alter their preferences, goals, frames, and commitments".

Besides political mobilisation, $\mathrm{C} 40$ has also offered technical assistance to its members such as the flagship 'Deadline2020' programme which facilitates cities to progress climate action plans for achieving the Paris Agreement's global warming 1.5oC target. This was initiated with a group of eight pilot cities that are working collaboratively to establish a common climate action planning framework. The $\mathrm{C} 40$ Cities Finance Facility (CFF) also provides the network members with certain supports (including helping cities in preparing projects' proposals) to get access to finance from international economic institutions for implementing climate initiatives (Pinault and Hansen, 2018). In sum, the support of C40 for its members is generally catalytic, and C40 cities are both receiving and exchanging resources in turn when participating within different activities of the network (Pinault and Hansen, 2018).

In addition, the Good Practice Guides and the Cities 100 report seek to showcase tangible examples of climate change actions via 100 case studies derived from cities around the world of different geography, size and phases of development. The Good Practice Guides comprise approximately 70 categories of commended initiatives which seek to reduce climate risk, address climate change and promote sustainable urban development within various sectors, including the transport, adaptation and finance, solid waste management, urban planning and energy sectors. By contrast, the Cities 100 report select the most ground-breaking projects based on five key criteria (which are climate action, co-benefits, innovation, governance, sharing and scaling) covering five city sectors (energy, waste, adaptation, mitigation and transportation) (Sustainia, C40 and Realdania, 2017). With the provisions of these two reports, the $\mathrm{C} 40$ expects that cities within its network and beyond will adapt and replicate best practices and thus engage in meaningful climate actions 'more quickly, at a lower cost and achieve greater impact than if they were acting alone' (C40, 2016c, p. 1).

The C40 Cities Awards were first established in 2013 to reward cities with the best climate action practices around the world. These awards also seek to showcase and share success stories or performance accounts 'so that other cities will be inspired and empowered to act' (C40, 2016b). In 2017, the Awards placed a significant focus on the leadership of US cities, in which each of five categories (Cities4Energy, Cities4ZeroWaste, Cities4Action, 
Cities4Tomorrow and Cities4Mobility) had two winners: one American city and one city from the rest of the world $(\mathrm{C} 40,2019 a)$.

Finally, C40 is also facing the challenge of 'scaling' actions to achieve more meaningful impacts (Hoffman, 2011; Gordon 2013). In this instance, Luederitz et. al (2017) identifies two key typologies of scaling, which are 'scaling out' (repeating climate initiatives within similar contexts) and 'scaling up' (integrating and applying innovative actions at higher system levels). Based on data from C40, Smeds and Acuto (2018, p. 553) argue that climate actions undertaken by C40 member cities "materially result in "scaling out" of experiments globally, rather than "scaling up" beyond the urban level of governance'. It is indisputable that city governments have the necessary jurisdictional powers to expand climate actions within their boundaries and can share knowledge about these initiatives via $\mathrm{C} 40$, facilitating 'scaling out' to other city members. However, both cities and city networks such as C40 possess very limited powers to effectively lobby 'national and multilateral policy frameworks? (Smeds \& Acuto, 2018, p. 554). Although C40 has been actively engaging with international agendas (including the United Nations Framework Convention on Climate Change (UNFCCC) and the Habitat III United Nations Urban Agenda) and has generated media pressure on national leaders (via C40 mayors), Smeds and Acuto (2018, p. 554) observe that " $\mathrm{C} 40$ is still "not at the table" of multilateral negotiations and national policymaking'.

Climate Action in Megacities (CAM) is the title of a set of key reports that collated and counted the climate actions of participating cities in 2011, 2014 and 2015. Bloomberg, the current president of the $\mathrm{C} 40$ Board of Directors, described these reports as 'a roadmap' for facilitating the scope of knowledge transfer and climate action collaborations between megacities (C40, 2015, p. 2). The themes identified in the three reports are consistent. The actions of cities in responding to climate change threats were measured across twelve sectors (i.e., the water, waste, private transport, outdoor lighting, mass transit, information communication technology, food and agriculture, finance and economic development, energy supply, community-scale development, buildings and adaptation sectors). Along with the CAM report, Deadline 2020, which was delivered by C40 and Arup (n.d.), is another significant route map for cities to achieve the objectives of Paris Agreement. This report outlined the scale, pace and prioritisation of actions needed to be taken by $\mathrm{C} 40$ cities over the next five years and beyond (C40 and Arup, n.d.). 
To summarise, C40 facilitates knowledge creation and distribution through a hybrid form of Darwinian / evolutionary experimentation and generative experimentation. It orchestrates this globally distributed form of experimentation through cross-sectoral political mobilization, technical assistance and various forms of standard / best-practice setting. Most learning in the network is of a technical / epistemic nature which explains the tendency for experiments to mostly scale out rather than scale up (Smeds and Acuto, 2018). Research is needed on a more granular level of the knowledge networking to hone in on the individual actors in order to unpack the micro foundations of the city networks. Research on this local-global interplay of knowledge dynamics in the C40 network thus provides a fruitful area of inquiry at the intersections of transition and innovation studies, urban studies, political science and human geography. In doing so future studies would benefit from adopting a network ontology following the constituents and connections of knowledge networks in urban climate experimentation, wherever they lead, rather than employing scalar envelopes (Coenen et al., 2012; Binz and Truffer, 2017). This raises interesting and pressing questions about the politics and geographies of policy mobilities and experiments where expertise and epistemic communities are inherently 'glocal' (Sengers and Raven, 2015)

\section{Theme 3: How city networks shape key urban institutions}

What are the implications of city networks for traditional institutions that have in the past shaped urban strategy, development and government?

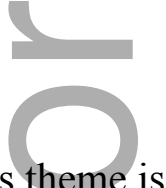

First in this theme is to raise the issue of the politico-institutional implications of these new and increasingly institutionalised circuits for the conventional planning regimes in networked cities - and in some instances the wider planning regions within which $\mathrm{C} 40$ actions occur. Networked urbanism and actions potentially challenge the status, methods, and institutional relevance of traditional planning in ways that have not yet been considered in practice and scholarship. For example, they may significantly shift the focus of urban policy, including planning, from land use regulation towards more ephemeral project related actions - the 'evolutionary and generative experimentation' that we pointed to earlier in our assessment of C40 networking. The experimental, project/solution focus of networked urbanism differs profoundly from the traditional method of city planning, at least in the Anglosphere, which has emphasised comprehensive scale planning, often rooted in long run trend assessment of 
social and physical development patterns. Thus, networked urbanism could be defined as a potentially disruptive urbanism against the backdrop of modernist, and more lately neoliberal, metropolitan planning. We identify this as a possibility not a certainty because it is equally plausible that both urban modes, the traditional and the networked, could coexist as 'parallel policy universes', each hardly influencing the other. Preliminary assessment suggests that such detachment has occurred in Melbourne (Davidson \& Gleeson 2018). Over the longer term, the situation could be dynamic, registering distinct periods of detachment and convergence and perhaps contradiction. Further, such networking potentially drives exogenous changes to means and methods of city shaping which have traditionally been framed by largely localised, or at least nationally or regionally conditioned, planning institutions and knowledges.

We found that networked urbanism tends to scale outwards rather than upwards - and this feature is shared with many forms of city planning that poorly articulate with larger governance scales (regional and national). However, the observed centrifugal power of networked experimentation further confirms its potential to disrupt or in some measure transform embedded urbanisms at the metropolitan scale. Moreover, there is evidence to suggest that city networks may prove more effective at higher political articulation than traditional metropolitan planning regimes. They are 'pushing and prodding' nation-state governments (Gordon and Johnson, 2018), with the hope that governments will increase the ambition and efficacy of national climate governance (Michaelowa \& Michaelowa 2017; Roger et al., 2017; Green 2015). Broekhoff et al. (2015) and Macedo et al. (2016) have called for city networks to be 'critical implementers' and 'strategic partners' of the national government, as opposed to autonomous actors pursuing emissions reductions on their own. Scholars also call for better synergies and connections between city networks and inter-state initiative (Hsu et al., 2017)

Second, we reflected above on the power relations and political economy at work in 'networked diplomacy' and which cannot be neglected by critical analysis. Such critical consideration flags the implications for public interests and public processes that may lurk within the apparent 'goodwill and good actions' of philanthropic networks, such as C40, that have strong corporate foundations and ethos. The C40 is engaged by a diverse set of actors, for example, private corporations, philanthropic organisations, development banks, cities, and environmental groups. This raises the potential for complex power relations where the 
interplay of different sectoral rationale (profit, public interest, local priorities, etc) may potentially inhibit collective purpose.

Our finding that the $\mathrm{C} 40$ network is infusing a logic of Darwinian experimentation on its participants is suggestive of these power modalities, including the manifest ascendency of US and European city members in setting standards and 'best practices', raising the question of the global North's wider political economic hegemony. On the other hand, it should be recognised that $\mathrm{C} 40$ has made significant efforts to widen its framework to the Global South, engaging cities in China, Latin America and Africa. Further, we noted the importance of power at the agentic scale - the common presence of influential actors, including political leaders - which underlines the necessity of examining networking at multiple socio-political scales. In contexts marked by new networked diplomatic plays outside the norms of long standing institutions and political frames, economic resilience may take quiet, even unconscious, priority over social and soladaristic values. Scrutiny by civil society and critical scholarship is invited to assess these risks and identify any manifest tendencies to corporate or sectional prerogative. We emphasise that this observation points to potential not actually observed instances of narrow prerogative.

Finally, after pointing to some potentially retrograde effects of networking above, we acknowledge equally its potential to effect through novel means needed and timely changes to city resilience. (This is a general observation about city networking, which takes many forms, not the $\mathrm{C} 40$ model per se.) As we observed, the networked urbanism we have reviewed differs from traditional planning by emphasising relatively fluid fast-moving programs, actions and behavioural changes over the slower conventional means for city shaping, especially land use regulation. It may therefore possess a level of efficacy that planning does not in dealing with certain contemporary urban priorities - notably climate mitigation and social resilience. This, however, is not clear and will have to be established through rigorous evaluation and scholarship - based on emerging evidence Fainstein (2018) suggests such efficacy may be more apparent than real. A challenge surely arises to align and potentially synthesise these traditional and new forms of city shaping in the so-called global urban age.

We conclude by offering key research questions for critical comment that provide a point of entry for further interrogation of the implications of city networks for traditional planning 
regimes. Firstly, the experimental, project/solution focus of city networks, differs profoundly from the traditional method of city planning that emphasises comprehensive scale planning rooted in long run trend assessment of social and physical development patterns. Further investigation is required into whether the methods of city networks could be defined as a potentially disruptive urbanism. Or are these methods co-opted by or layered on top of the instruments and policy levers of traditional planning regimes? Secondly, what are the implications of city networks for traditional planning institutions, including the possibility that they may corrode their authority and resourcing? Thirdly, and developing the question of possible disruption to traditional planning institutions, we invite further interrogation of whether city networks are more effective at higher political articulation than traditional metropolitan planning regimes? Is there a role for city networks as 'critical implementers' and 'strategic partners' of the national government, as opposed to autonomous actors pursuing discrete targets and missions on their own? In questioning the effectiveness of city networks at higher political articulation we also suggest the consideration of whether networks possess a level of efficacy that planning does not in dealing with certain contemporary urban priorities. This requires close empirical evaluation of experiments and initiatives relative to outcomes from embedded planning processes. Importantly, the questions we raise suggest that both new knowledge and action are needed to ensure these powerful and innovative forces for urban change (possibly disruption) align closely with what is arguably the gravest consideration in the urban age, the imminent threat to planetary well-being from climate warming.

Kathryn Davidson in a Senior Lecturer at the University of Melbourne who has achieved international recognition as a scholar in urban governance, drawing on the extensive work she has done on Australian metropolitan climate strategies.

Brendan Gleeson is the Director of the Melbourne Sustainable Society Institute, at the University of Melbourne. Brendan has made significant scholarly contributions in urban and social policy, environmental theory and policy. Brendan is a Fellow of the Australian Academy of Social Sciences.

Lars Coenen joined the Melbourne Sustainable Society Institute at the University of Melbourne in January 2017 as the inaugural 'City of Melbourne Chair of Resilient Cities'. 
Prior to that he was professor in innovation studies at Lund University, Sweden. Lars is wellknown internationally for his work on regional and urban innovation and sustainability transitions.

\section{References}

Acuto, M 2011, 'Finding the global city: an analytical journey through the 'invisible college', Urban Studies, vol. 48, no. 14, pp. 2953-2973.

Ansell, CK \& Bartenberger, M 2016, 'Varieties of experimentalism', Ecological Economics, vol. $130, \mathrm{pp} .64-73$.

Aust, HP 2015, 'Shining cities on the hill? The global city, climate change, and international law', The European Journal of International Law, vol. 26, no. 1, pp. 255-278.

Bansard, J, Pattberg, P \& Widerberg, O 2017, 'Cities to the rescue? Assessing the performance of transnational municipal networks in global climate governance', International Environmental Agreements: Politics, Law and Economics, vol. 17, no. 2, pp. 229-246. Binz, C \& Truffer, B, 2017. 'Global Innovation Systems-A conceptual framework for innovation dynamics in transnational contexts', Research Policy, vol. 46, no. 7, pp.12841298.

Bouteligier, S 2015, 'Multinational companies and urban climate governance: market making or successful policy innovation?', in C Johnson, N Toly \& H Schroeder (eds), The Urban Climate Challenge, Routledge.

Broekhoff, D, Erickson, P \& Lee, C 2015, What cities do best: piecing together an efficient global climate governance.

Broto, VC \& Bulkeley, H 2013, 'Maintaining climate change experiments: Urban political ecology and the everyday reconfiguration of urban infrastructure', International Journal of Urban and Regional Research vol. 37, pp. 1934-1948.

Bulkeley, H, Edwards, GAS \& Fuller, S 2014, 'Contesting climate justice in the city: examining politics and practice in urban climate change experiments', Global environmental change, vol. 25, pp. 31-40.

Busch, H \& Anderberg, S 2015, 'Green attraction - transnational municipal climate networks and green city branding', Journal of Management and Sustainability, vol. 5, no. 4, pp. 1-16.

Coenen, L, Benneworth, P \&Truffer, B 2012, 'Toward a spatial perspective on sustainability transitions', Research policy, vol. 41, no. 6, pp.968-979. 
C40, 2015c40. CAM 3.0 [online]. https://issuu.com/c40cities/docs/cam_3.0_2015 [Accessed 2 April 2016].

C40 2016a, Unlocking Climate Action on Megacities, C40. viewed 10 May 2017, $<$ http://www.c40.org/researches/unlocking-climate-action-in-megacities $>$.

C40 2016b, 'C40 Cities Awards 2016', C40, viewed 10 April 2018, $<$ https://www.c40.org/events/c40-cities-awards-2016 $>$.

C40 2016c, 'Roadmaps for successful climate action: C40 cities share 100 case studies proven to work', $C 40$, p. 1.

C40 2019a, 'C40 Cities Bloomberg Philanthropies Awards', <https://www.c40.org/awards $>$.

C40 2019b, 'Network', C40, <https://www.c40.org/networks $>$.

C40 2019c, 'Programmes', C40, <https://www.c40.org/programmes $>$.

C40 \& Arup n.d, Deadline2020, C40 and Arup. < $\underline{\text { https://www.c40.org/researches/deadline- }}$ $\underline{2020}>$.

CCFLA 2015, The state of city climate finance, Cities Climate Finance Leadership Alliance. CDP 2016, The Low-carbon Investment Landscape in C40 Cities: An Analysis of the Sustainable Infrastructure Projects Currently in Development Across C40 cities, C40. CFUT 2016, Shaping Urban Transitions. The Coalition for Urban Transitions. Better Cities, Better Growth, Better Climate, World Resources Institute Ross Center for Sustainable Cities. viewed 3 May 2017, < $\underline{\text { http://newclimateeconomy.report/workingpapers/wp- }}$ content/uploads/sites/5/2017/06/Shaping-Urban-Transitions.pdf $>$.

Davidson, K \& Gleeson, B 2018, 'New socio-ecological imperatives for cities: possibilities and dilemmas for Australian metropolitan governance', Urban Policy and Research, vol. 36, no. 2 , pp. $230-241$

Davidson, K. \& Gleeson, B 2014 'The sustainability of an entrepreneurial city', International Planning Studies, vol. 19, no.2, pp.173-191

Davidson, K. \& Gleeson, B 2015 'Interrogating urban climate leadership: towards a political ecology of the C40 network', Global Environmental Politics, vol. 15. no.4, pp.21-37

Evans, J 2011, 'Resilience, ecology and adaptation in the experimental city', Transactions of the Institute of British Geographers, vol. 36, no. 2, pp. 223-237.

Evans, J, Karvonen, A \& Raven, R (eds) 2016, The experimental city, Routledge, New York. Falkner, R 2016, 'The Paris Agreement and the new logic of international climate politics', International Affairs, vol. 92, no. 5, pp. 1107-1125.

This article is protected by copyright. All rights reserved 
Fraundorfer, M 2017, 'The role of cities in shaping transnational law in climate governance', Global Policy, vol. 8, no. 1, pp. 23-31.

Gleeson, B \& Spiller, M 2012 'Metropolitan governance in the urban age: trends and questions', Current Opinion in Environmental Sustainability, vol. 4, pp. 393-7

Green, J 2015, 'The strength of weakness: pseudo-clubs in the climate regime', Climate Change, pp.1-12.

Hakelberg, L 2014, 'Governance by diffusion: transnational municipal networks and the spread of local climate strategies in Europe', Global Environment Politics, vol. 14, pp. $107-$ 129.

Hickmann, T 2016, Rethinking Authority in Global Climate Governance: How Transnational Climate Initiatives Relate to the International Climate Regime, Routledge, New York.

Hsu, A, Cheng, Y, Weinfurter, A, Xu, K \& Yick, C 2016, 'Track climate pledges of cities and companies', Nature, vol. 532, pp. 303-306.

Hughes, S 2016, 'The politics of urban climate change policy: toward a research agenda', Urban Affairs Review, pp. 1-19.

Kern, K \& Bulkeley, H 2009, 'Cities, Europeanization and multi-level governance: governing climate change through transnational municipal networks', Journal of Common Market Studies, vol. 47, pp. 309-332.

Lee, T \& Jung, HY 2018, 'Mapping city-to-city networks for climate change action: Geographic bases, link modalities, functions, and activity', Journal of Cleaner Production, vol. 182 , pp. 96-104.

Macedo, L, Setzer, J \& Rei, F 2016, 'Transnational action fostering climate protection in the City of Sao Paulo and beyond', disP - The Planning Review, vol. 52, pp. 35-44.

Merrifield, A 2013, 'The urban question under planetary urbanization', International Journal of Urban and Regional Research, vol. 37, no. 3, pp. 909-922.

Michaelowa, K \& Michaelowa, A 2017, 'Transnational climate governance initiatives: designed for effective climate change mitigation?', International Interaction, vol. 43, pp. 129155.

Pinault, E, and Hansen, S 2018, 'Mayors On The Global Stage: A Political Star Is Born', Økonomi \& Politik, vol. 91, n. ${ }^{\text {o } 3 \text {, septiembre } 2018 .}$

Roger, C, Hale, T \& Andonova, L 2017, 'Domestic politics and climate governance', International Interaction, vol. 43, pp. 1-25. 
Sabel, CF \& Zeitlin, J (eds) 2010, Experimentalist Governance in the European Union, Oxford University Press, Oxford.

Sassen, S 2014, Cities in a World Economy 4th Edition, Sage, London.

Sengers, F \& Raven, R 2015, 'Toward a spatial perspective on niche development: The case of Bus Rapid Transit', Environmental Innovation and Societal Transitions, vol. 17, pp.166182.

Sustainia, C40 \& Realdania 2017, Cities 100 2017, Sustainia and C40.

$<$ https://issuu.com/sustainia/docs/cities 100 2017> .

Swyngedouw, E \& Heynen, N 2003, 'Urban political ecology, justice and the politics of scale, Antipode, vol. 35, no.5, p.p. 898-918

Toly, NJ 2008, 'Transnational municipal networks in climate politics: from global governance to global politics', Globalizations, vol. 5, no. 3, pp. 341-356.

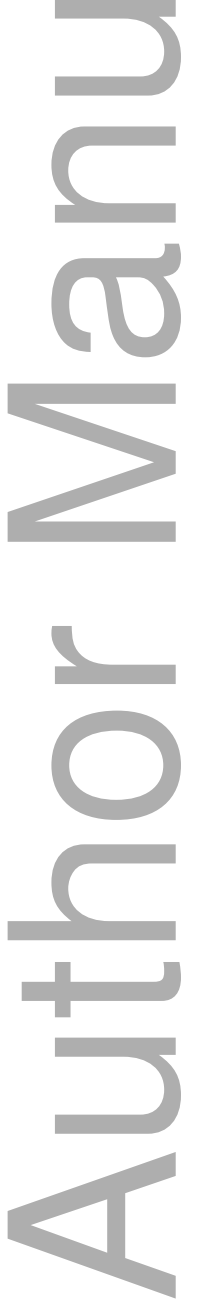


Appendix 1: C40 networks

\begin{tabular}{|c|c|c|c|c|}
\hline Key Area & Network & Aim & Lead City & Focus Area \\
\hline \multirow[t]{3}{*}{$\begin{array}{l}\text { Adaptation and } \\
\text { Implementation }\end{array}$} & $\begin{array}{l}\text { Urban } \\
\text { Flooding }\end{array}$ & $\begin{array}{l}\text { To support cities to address the influences } \\
\text { of floods within urban space }\end{array}$ & Not stated & $\begin{array}{l}\text { Measuring and monitoring urban flooding; } \\
\text { flood response; flood reduction; governance } \\
\text { and holistic water management }\end{array}$ \\
\hline & $\begin{array}{l}\text { Connecting } \\
\text { Delta Cities }\end{array}$ & $\begin{array}{l}\text { To support coastal delta cities to tackle } \\
\text { climate change threats by exchanging } \\
\text { knowledge and sharing successful } \\
\text { practices to help cities develop their own } \\
\text { climate solutions }\end{array}$ & Rotterdam & $\begin{array}{l}\text { Systematic adaptation; sustainable urban } \\
\text { drainage; monitoring and evaluation; cost- } \\
\text { benefit and co-benefit assessments }\end{array}$ \\
\hline & Cool Cities & $\begin{array}{l}\text { To support city members to mitigate the } \\
\text { effect of the urban heat island effect by } \\
\text { encouraging collaborations and knowledge } \\
\text { sharing between cities and by working in } \\
\text { partnership with the Global Cool Cities } \\
\text { Alliance }\end{array}$ & Athens & $\begin{array}{l}\text { UHI data monitoring and measurement; } \\
\text { integrating heat into long-term planning; green } \\
\text { and cool solutions; heat health vulnerability }\end{array}$ \\
\hline Air Qua & Air Quality & $\begin{array}{l}\text { To support cities in developing and } \\
\text { implementing air quality solutions and } \\
\text { policies to address climate change }\end{array}$ & $\begin{array}{l}\text { Bengaluru } \\
\text { and London }\end{array}$ & $\begin{array}{l}\text { Monitoring and measurement; health impact } \\
\text { analysis; making the case; policy } \\
\text { implementation }\end{array}$ \\
\hline
\end{tabular}

This article is protected by copyright. All rights reserved 


\begin{tabular}{|c|c|c|c|c|}
\hline $\begin{array}{l}\text { Energy and } \\
\text { Buildings }\end{array}$ & $\begin{array}{l}\text { Municipal } \\
\text { Building } \\
\text { Efficiency }\end{array}$ & $\begin{array}{l}\text { To support efforts of cities in enhancing } \\
\text { the energy efficiency of the buildings that } \\
\text { they own, lease or manage }\end{array}$ & Cape Town & Data; finance; behaviour; governance \\
\hline & Clean Energy & $\begin{array}{l}\text { To support city efforts in planning and } \\
\text { implementing solutions to increase low } \\
\text { carbon energy supply for cities }\end{array}$ & $\begin{array}{l}\text { City of } \\
\text { Vancouver }\end{array}$ & $\begin{array}{l}\text { Municipal clean energy strategy; thermal } \\
\text { energy; business models; stakeholder } \\
\text { engagement; energy resilience and security }\end{array}$ \\
\hline & $\begin{array}{l}\text { New } \\
\text { Building } \\
\text { Efficiency }\end{array}$ & $\begin{array}{l}\text { To support cities to plan and implement } \\
\text { energy efficiency programmes and policies } \\
\text { during the process of constructing and } \\
\text { commissioning new buildings }\end{array}$ & Not stated & $\begin{array}{l}\text { Getting to net zero carbon; measurement and } \\
\text { verification; stakeholder engagement; } \\
\text { compliance and enforcement }\end{array}$ \\
\hline & $\begin{array}{l}\text { Private } \\
\text { Building } \\
\text { Efficiency }\end{array}$ & $\begin{array}{l}\text { To help cities to enhance the energy } \\
\text { efficiency of existing residential and } \\
\text { commercial buildings to reduce carbon } \\
\text { emissions, energy bills and create healthier } \\
\text { workplaces, new jobs and greater energy } \\
\text { security }\end{array}$ & $\begin{array}{l}\text { Sydney and } \\
\text { San } \\
\text { Francisco }\end{array}$ & $\begin{array}{l}\text { Data for policy; residential buildings; deep } \\
\text { retrofit; commercial buildings }\end{array}$ \\
\hline $\begin{array}{l}\text { Food, Waste and } \\
\text { Water }\end{array}$ & $\begin{array}{l}\text { Sustainable } \\
\text { Solid Waste } \\
\text { Systems }\end{array}$ & $\begin{array}{l}\text { To support cities in delivering a holistic } \\
\text { approach to their waste management } \\
\text { operations by promoting innovative } \\
\text { technologies }\end{array}$ & $\begin{array}{l}\text { Delhi and } \\
\text { Durban }\end{array}$ & $\begin{array}{l}\text { Improving solid waste management systems; } \\
\text { waste recovery and disposal mechanisms; } \\
\text { social inclusion }\end{array}$ \\
\hline
\end{tabular}

This article is protected by copyright. All rights reserved 


\begin{tabular}{|c|c|c|c|c|}
\hline \multirow{2}{*}{$\underbrace{10}_{1}$} & $\begin{array}{l}\text { Food } \\
\text { Systems }\end{array}$ & $\begin{array}{l}\text { To support cities in creating and } \\
\text { implementing innovative solutions to } \\
\text { decrease carbon emissions and increase } \\
\text { resilience via the urban food system }\end{array}$ & Not stated & $\begin{array}{l}\text { Food procurement; food production; food } \\
\text { distribution; food waste }\end{array}$ \\
\hline & $\begin{array}{l}\text { Waste to } \\
\text { Resources }\end{array}$ & $\begin{array}{l}\text { To facilitate the transition from solid waste } \\
\text { management to sustainable materials } \\
\text { management }\end{array}$ & Not stated & $\begin{array}{l}\text { Segregated collection; minimization and } \\
\text { diversion initiatives; food waste avoidance and } \\
\text { reduction; waste greenhouse gas accounting; } \\
\text { beyond waste management roadmaps }\end{array}$ \\
\hline \multirow{2}{*}{$\begin{array}{l}\text { Transportation } \\
\text { and Urban } \\
\text { Planning }\end{array}$} & $\begin{array}{l}\text { Land Use } \\
\text { Planning }\end{array}$ & $\begin{array}{l}\text { To assist cities in the development of } \\
\text { efficient land use planning with relevant } \\
\text { policies to enhance connected and compact } \\
\text { urban growth and development }\end{array}$ & $\begin{array}{l}\text { Mexico } \\
\text { City }\end{array}$ & $\begin{array}{l}\text { Comprehensive planning for denser, } \\
\text { more liveable cities; enabling transit-oriented } \\
\text { development; integrating climate change and } \\
\text { adaptation priorities into land use plans and } \\
\text { policies }\end{array}$ \\
\hline & $\begin{array}{l}\text { Zero } \\
\text { Emission } \\
\text { Vehicles } \\
(\mathrm{ZEV})\end{array}$ & $\begin{array}{l}\text { To facilitate the uptake Zero Emission } \\
\text { Vehicles within cities }\end{array}$ & London & $\begin{array}{l}\text { City-wide ZEV strategies; infrastructure; } \\
\text { incentives; fleets }\end{array}$ \\
\hline
\end{tabular}

This article is protected by copyright. All rights reserved 


\begin{tabular}{|c|c|c|c|c|}
\hline & Mass Transit & $\begin{array}{l}\text { To support cities in improving mass transit } \\
\text { and its coverage, experience to make it } \\
\text { more attractive, integrated and accessible } \\
\text { to use }\end{array}$ & Not stated & $\begin{array}{l}\text { Choosing the right mass transit solution; } \\
\text { enhancing mass transit; physical and } \\
\text { operational integration }\end{array}$ \\
\hline & $\begin{array}{l}\text { Walking and } \\
\text { Cycling }\end{array}$ & $\begin{array}{l}\text { To help cities to increase the number of } \\
\text { sharing trips taken by safe, carbon-free and } \\
\text { healthy mobility options }\end{array}$ & Not stated & $\begin{array}{l}\text { Making the case; infrastructure planning; } \\
\text { infrastructure design; infrastructure financing; } \\
\text { safety and security; bike sharing }\end{array}$ \\
\hline & $\begin{array}{l}\text { Mobility } \\
\text { Management }\end{array}$ & $\begin{array}{l}\text { To help cities to enhance integration across } \\
\text { transit modes, make public transit become } \\
\text { more attractive and easier to utilise, reduce } \\
\text { and re-distribute travel demands to unlock } \\
\text { transport systems' capacity. }\end{array}$ & Paris & $\begin{array}{l}\text { Integrated transport planning; ticketing; } \\
\text { parking and private vehicle management; } \\
\text { congestion pricing; communications and travel } \\
\text { planning campaigns }\end{array}$ \\
\hline
\end{tabular}

Sources: Adapted from C40, 2019b.

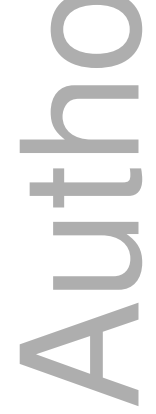

This article is protected by copyright. All rights reserved 
The C40's projects and programmes

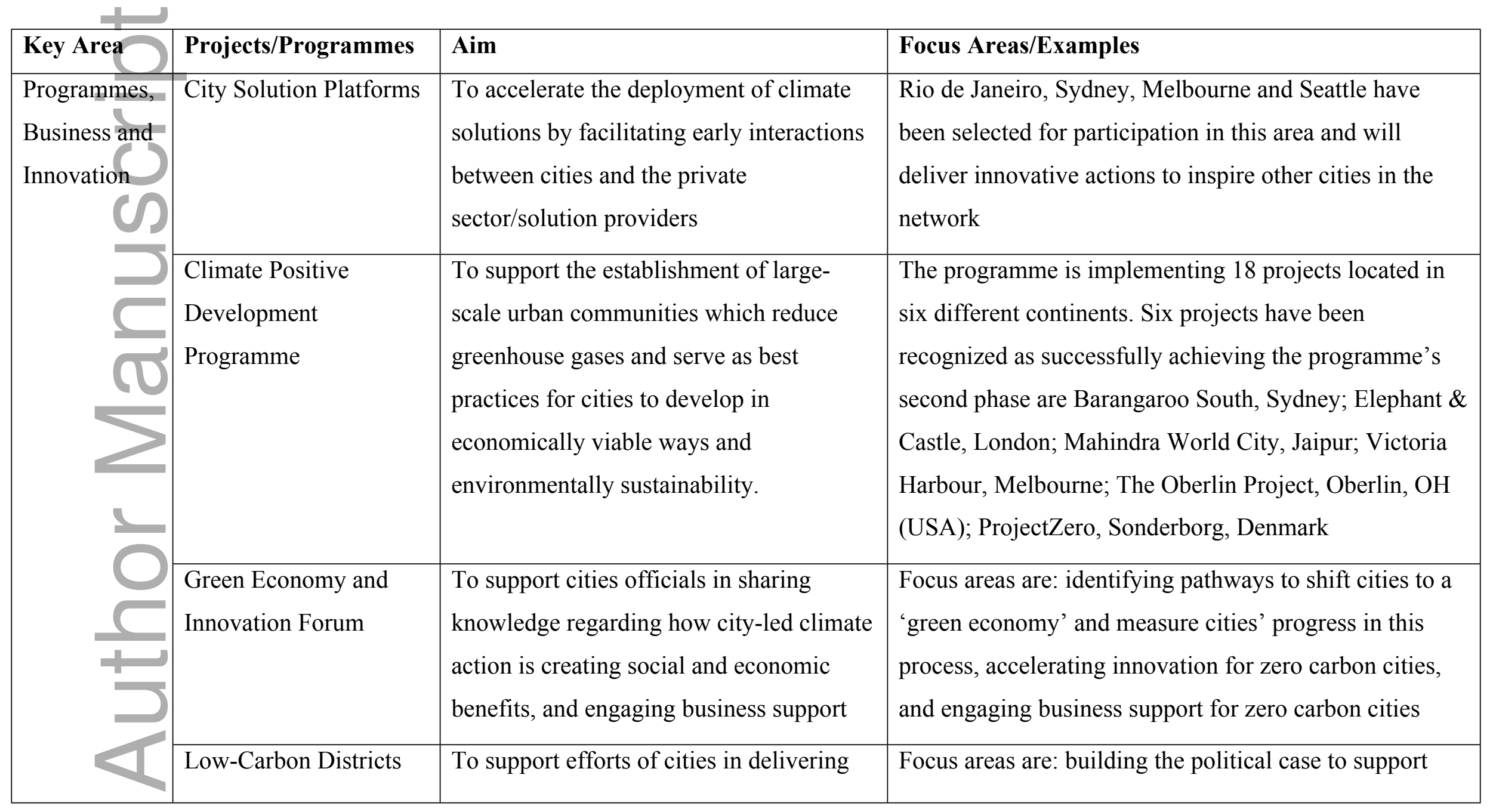

This article is protected by copyright. All rights reserved 


\begin{tabular}{|c|c|c|c|}
\hline 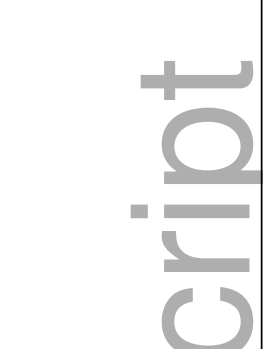 & Forum & $\begin{array}{l}\text { low-carbon, district-scale development } \\
\text { projects, including Climate Positive } \\
\text { Development projects }\end{array}$ & $\begin{array}{l}\text { ambitious low-carbon development targets, district-scale } \\
\text { development projects, strengthening partnerships and } \\
\text { increasing engagement with the private sector, } \\
\text { quantifying co-benefits and impacts of low-carbon } \\
\text { development, and climate positive development }\end{array}$ \\
\hline $\begin{array}{l}\text { City } \\
\text { Intelliger }\end{array}$ & City Intelligence & $\begin{array}{l}\text { To drive urban actions via the efficient } \\
\text { collection, management and use of city } \\
\text { information and data }\end{array}$ & $\begin{array}{l}\text { Focus areas are: enhancing access to knowledge and the } \\
\text { scale, speed of peer-to-peer connection, providing data } \\
\text { resources about C40 cities and conduct data analysis, } \\
\text { improving C40 cities' performance (reducing emissions } \\
\text { and climate risk) with efficient research and advocacy } \\
\text { efforts }\end{array}$ \\
\hline
\end{tabular}

This article is protected by copyright. All rights reserved 


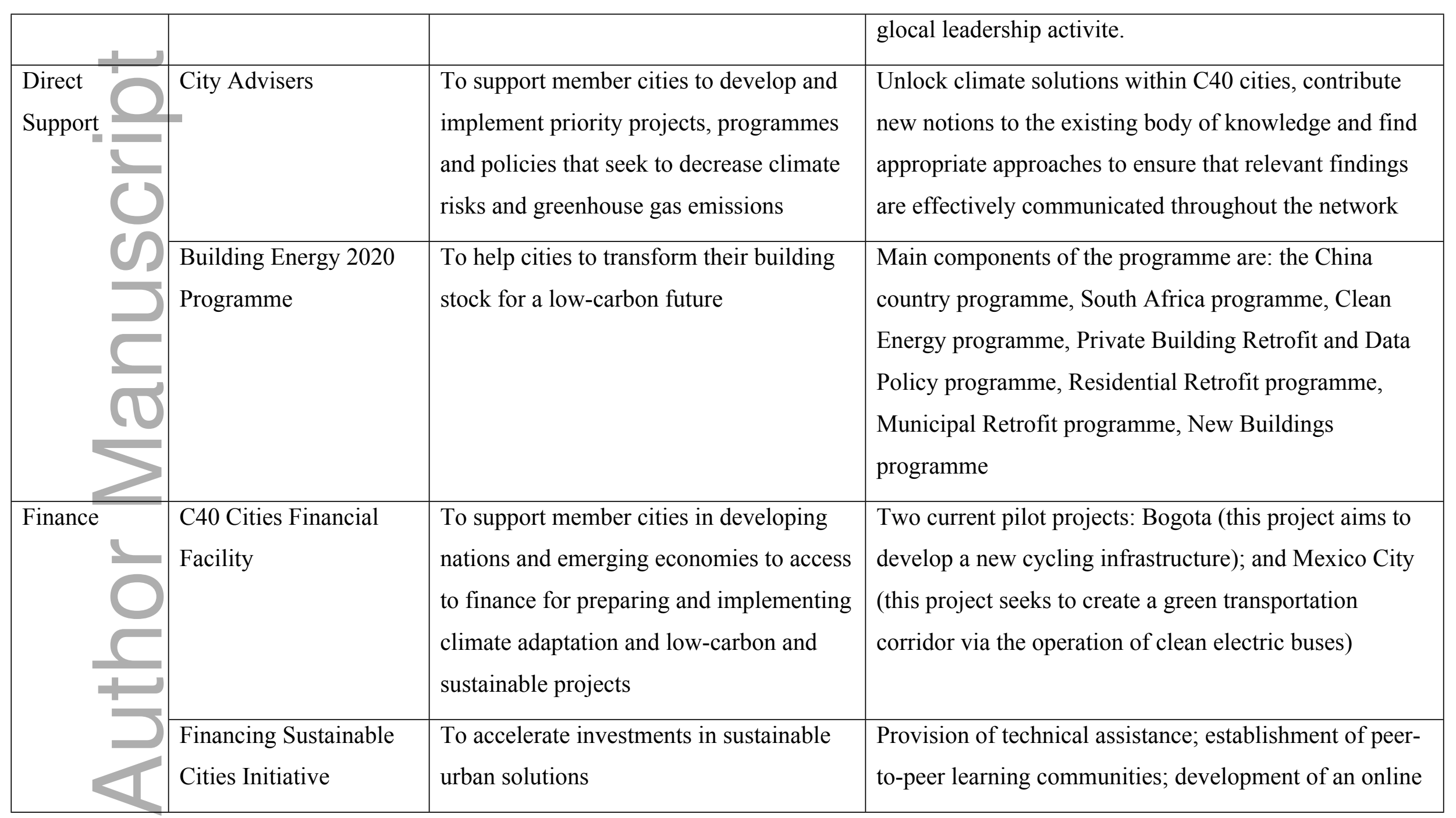

This article is protected by copyright. All rights reserved 


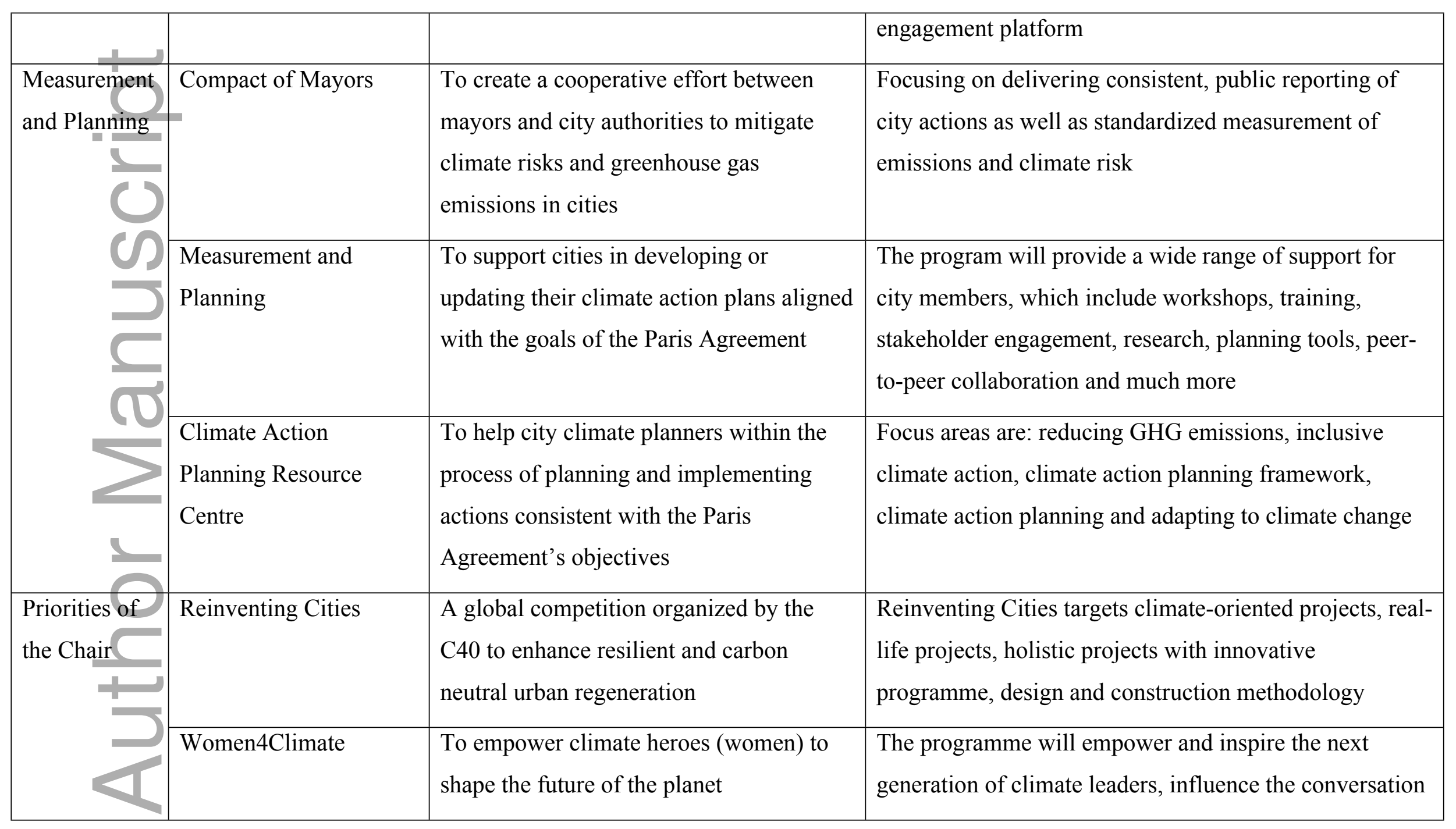

This article is protected by copyright. All rights reserved 


\begin{tabular}{|l|l|l|l|}
\hline Special & & $\begin{array}{l}\text { through leadership events and create a new vocation } \\
\text { among future leaders, drive action by launching an } \\
\text { annual challenge dedicated to the best innovations in } \\
\text { climate and sustainability, and raise awareness through } \\
\text { research on gender, cities and climate to highlight the } \\
\text { key role women play in championing climate policies }\end{array}$ \\
\hline Ancts & $\begin{array}{l}\text { To provide cities with an apparent } \\
\text { roadmap and support to deliver innovative } \\
\text { climate actions that is beneficial and } \\
\text { equitable for all }\end{array}$ & $\begin{array}{l}\text { Focus areas are: enhancing thought leadership of mayors } \\
\text { and the exchange of best practices between cities, } \\
\text { providing cities with technical assistance (including } \\
\text { training, research and access to resources) to develop } \\
\text { climate action plans }\end{array}$ \\
\hline
\end{tabular}

Sources: Adapted from C40, 2019c.

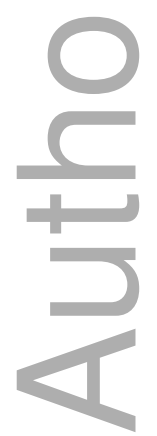

This article is protected by copyright. All rights reserved 


\section{University Library}

\section{- M M I N E R VA A gateway to Melbourne's research publications}

Minerva Access is the Institutional Repository of The University of Melbourne

Author/s:

Davidson, K;Coenen, L;Gleeson, B

Title:

A Decade of C40: Research Insights and Agendas for City Networks

Date:

2019

Citation:

Davidson, K., Coenen, L. \& Gleeson, B. (2019). A Decade of C40: Research

Insights and Agendas for City Networks. Global Policy, 10 (4), pp.697-708. https:// doi.org/10.1111/1758-5899.12740.

Persistent Link:

http://hdl.handle.net/11343/286813 